\title{
KORELASI KECEMASAN DAN DOMAIN KELELAHAN PADA PASIEN TUBERKULOSIS
}

\author{
Tasnim $^{1}$, Ferdy Lainsamputty ${ }^{2}$ \\ 1. Program Studi DIII Keperawatan Poso, Politeknik Kesehatan Kementerian Kesehatan Palu, \\ Sulawesi Tengah, 94652, Indonesia \\ 2. Program Studi S1 Keperawatan, Sekolah Tinggi Ilmu Kesehatan Husada Mandiri Poso, Sulawesi \\ Tengah, 94611, Indonesia
}

Corresponding E-mail: Lainsamputtyferdy@gmail.com

\begin{abstract}
Tuberculosis $(T B)$ is a major health problem in many countries worldwide, ranked at the same level as Human Immunodeficiency Virus (HIV). In patients with TB, anxiety comes from the worsening of disease that created feeling of distress and fatigue. This study aimed to examine the relationship between anxiety and fatigue domains among tuberculosis patients. This study used a descriptive correlation design with cross-sectional approach. Consecutive sampling technique was used to recruit 70 participants from a general hospital in Central Sulawesi Province, Indonesia. The questionnaires used were Hamilton Anxiety Rating Scale (HAM-A) and Multidimensional Assessment of fatigue (MAF). Descriptive statistics and Spearman Correlation used to examine the relationship between variables. Anxiety had a significant correlation with distress domain of fatigue $(r=0,24, p<0,05)$. Those who experienced greater anxiety suffered more mental fatigue.
\end{abstract}

Keywords: Anxiety disorder, fatigue, tuberculosis

\begin{abstract}
ABSTRAK
Tuberkulosis (TB) merupakan masalah kesehatan utama di berbagai negara di dunia, berada diperingkat sama dengan penyakit HIV yang mematikan. Kecemasan pada pasien TB bersumber dari progress memburuknya penyakit sehingga membuat pasien tertekan secara psikologis dan mengalami kelelahan. Penelitian ini bertujuan untuk mengetahui hubungan kecemasan dan domain kelelahan pada pasien tuberkulosis. Penelitian ini berjenis deskriptif korelasi dengan pendekatan potong lintang menggunakan 70 sampel, yang direkrut dengan teknik consecutive sampling dari salah satu rumah sakit umum daerah di Sulawesi Tengah. Kuesioner yang digunakan yaitu Hamilton Anxiety Rating Scale (HAM-A) dan Multidimensional Assessment of Fatigue (MAF). Statistik deskriptif dan korelasi Spearman digunakan untuk mencari hubungan antar variabel. Kecemasan memiiki korelasi yang siginifikan dengan domain tekanan kelelahan $(r=0,24, p<0,05)$. Partisipan dengan kecemasan berat, menderita kelelahan mental yang lebih parah.
\end{abstract}

Kata Kunci: Gangguan kecemasan, kelelahan, tuberkulosis

\section{PENDAHULUAN}

Tuberkulosis merupakan masalah kesehatan besar di berbagai negara di dunia. Berdasarkan Global Tuberculosis Report 2016 oleh World Health Organization (2016), TB bertengger pada posisi yang sama dengan infeksi Human Immunodeficiency Virus atau HIV sebagai penyakit menular paling mematikan di dunia. Pada tahun 2016 di dunia terdapat jumlah kasus TB sebanyak 10,4 juta insiden, jumlah ini sama dengan 120 kasus per 100.000 penduduk. Indonesia masuk dalam 5 negara dengan insiden kasus tertinggi bersama, Cina, India, Filipina, dan Pakistan. Jumlah kasus TB global ini didominasi di area Asia Tenggara (45\%) dan 
Afrika (25\%) (Kementerian Kesehatan Republik Indonesia, 2018).

Jumlah kasus baru TB di Indonesia pada tahun 2017 sebanyak 420.994 kasus. Angka ini didominasi oleh penderita berjenis kelamin lakilaki, dengan alasan utama kebiasaan merokok dan kurang patuh dalam mengonsumsi obat dalam jangka panjang (Kementerian Kesehatan Republik Indonesia, 2018).

Morbiditas psikiatrik seperti gangguan kecemasan cukup umum pada kasus TB. Penelitian-penelitian yang dilakukan pada berbagai negara menunjukkan prevalensi kecemasan pada pasien TB, yaitu $18,4 \%$ di China (Wang et al., 2018), 26\% di Turki (Yilmaz \& Dedeli, 2016), 38,4\% di Brazil (Santos, Lazzari, \& Silva, 2017), dan 41,5\% di Etiopia (Duko, Gebeyehu, \& Ayano, 2015). Bahkan di Pakistan, sekitar $65 \%$ pasien TB menderita kecemasan pada tingkat sedang hingga parah (Amreen \& Rizvi, 2016).

Adanya kecemasan pada pasien TB menyebabkan kepatuhan yang buruk terhadap pengobatan antituberkular sehingga mengakibatkan prognosis yang buruk, yang pada akhirnya meningkatkan morbiditas dan mortalitas akibat TB (Kumar, Kumar, Chandra, \& Kansal, 2016). Penyakit TB menyebabkan gangguan psikososial pada kehidupan pasien dan sering merasa lebih lelah dan lesu (Dias, de Oliveira, Turato, \& de Figueiredo, 2013). Sebuah studi pada pasien TB paru menemukan bahwa kejadian kelelahan setinggi $88 \%$ (Thedthong, Puwarawuttipanich, Saneha, \& Rongrunguang, 2021). Kelelahan juga merupakan salah satu gejala utama pada kasus tuberculosis hepatik, bersama demam, nafsu makan yang buruk, nyeri di area hati, dan hepatomegali (Liao, Zhang, \& Wu, 2015).

Informasi terkait kecemasan dan kelelahan pada pasien TB di Indonesia cukup terbatas. Oleh karena itu, penting untuk menginvestigasi tentang kecemasan dan faktor spesifik lainnya guna optimalisasi penatalaksanaan pasien tersebut.

\section{MATERIAL DAN METODE}

Penelitian ini menggunakan desain deskriptif korelasi dan berpendekatan crosssectional. Sampel direkrut dari departemen rawat jalan menggunakan teknik consecutive sampling dari sebuah rumah sakit umum daerah di Sulawesi Tengah pada bulan Juni-Juli 2018.
Kriteria inklusinya yaitu pasien yang terdiagnosa TB oleh dokter, dapat berkomunikasi dengan baik dalam Bahasa Indonesia, dan bersedia terlibat menjadi partisipan. Pasien TB dengan gangguan pernafasan berat dan demensia adalah kriteria ekslusi dalam penelitian ini. Secara keseluruhan, subjek penelitian ini sebanyak 70 orang.

Data demografi dikumpulkan dengan menggunakan kuesioner, termasuk di dalamnya umur, jenis kelamin, pendidikan, status pernikahan, pekerjaan, status merokok, dan durasi sejak onset menderita TB. Kecemasan dalam penelitian ini dievaluasi menggunakan kuesioner Hamilton Anxiety Rating Scale yang sering disebut HAM-A (Hamilton, 1959). Setiap item diberi skor pada skala 0 (tidak ada) hingga 4 (berat), dengan rentang skor total 0-56, di mana skor di bawah 17 menunjukkan tingkat keparahan ringan, 18-24 keparahan ringan sampai sedang dan 25-30 sedang sampai berat. HAM-A dirancang untuk pasien dengan diagnosis neurosis kecemasan Namun, kebiasaan diagnostik telah berubah dan konsep neurosis kecemasan telah diganti oleh konsep baru gangguan kecemasan yang terdiri gangguan panik, gangguan fobia dan umum gangguan kecemasan. Nilai Cronbach's alpha HAM-A dalam penelitian ini adalah 0,96 .

Alat ukur kelelahan dalam penelitian ini menggunakan kuesioner Multidimensional Assessment of Fatigue atau MAF (Belza, Henke, Yeun, Epstein, \& Gauss, 1993). Secara keseluruhan ada 16 pertanyaan dalam kuesioner, namun hanya pertanyaan nomor 1-15 yang dapat digunakan untuk mengkalkulasi Global Fatigue Index atau GFI. Skor terendah yang bisa didapat partisipan dimulai dari 1 (tidak lelah) sampai 50 (sangat lelah). Kelelahan dalam kuesioner ini terbagi menjadi 4 domain: Keparahan/severity (pertanyaan nomor 1-2), tekanan/distress (3), waktu/timing (15-16) dan gangguan beraktivitas sehari-hari/degree of interference on $A D L$ (414). MAF digunakan untuk mendeskripsikan status kelelahan selama seminggu terakhir.

Skor GFI didapat dengan mengubah hasil jawaban pertanyaan nomor 15 ke dalam skala 0 10 , dengan cara mengalikan dengan 2,5. Hasil tersebut kemudian ditambahkan dengan jawaban pertanyaan nomor 1,2 , dan 3 , beserta nilai ratarata dari jawaban nomor 4-14. Skor tidak dapat dihitung bila partisipan mencentang beberapa kotak di sebelah nomor pertanyaan sebagai indikator bahwa mereka tidak melakukan 
aktivitas terkait. Jika partisipan memilih tidak merasa kelelahan pada pertanyaan nomor 1 , maka harus diberikan skor 0 semua pertanyaan yang tersisa (2-16). Kuesioner ini sudah digunakan pada populasi di Indonesia seperti pada pasien hemodialisis (Khusniyati, Yona, \& Kariasa, 2019) dan gagal jantung (Lainsamputty \& Chen, 2018). Skor uji reliabilitas konsistensi interlah kuesioner MAF dalam penelitian ini adalah 0,95 .

Sebelum dilakukan pengumpulan data, penelitian ini telah mendapatkan izin dari rumah sakit tempat dilakukannya penelitian dengan No.: 1111/420/2018. Pasien yang memiliki kesesuaian dengan kriteria inklusi, diarahkan oleh perawat saat kunjungan ke departemen rawat jalan. Setelah itu penjelasan tentang tujuan dan prosedur penelitian diberikan secara detail. Ketika setuju untuk berpartisipasi, pasien kemudian dikontak langsung oleh peneliti secara perorangan. Data partisipan dijaga dengan ketat dan hanya dipergunakan untuk kepentingan penelitian semata. Lembar informed consent wajib diisi oleh partisipan. Partisipan dapat mengundurkan diri kapanpun bila merasakan ketidaknyamanan dalam penelitian. Pengambilan data dilakukan dengan wawancara dan mengisi kuesioner.

Data penelitian dianalisa menggunakan perangkat lunak komputer spesifik tentang statistik. Pendekatan statitik dalam penelitian ini berupa: 1) Statistik deskriptif (rata-rata, simpang baku, frekuensi, dan persentase); 2) Korelasi Spearman digunakan untuk menguji hubungan antara kecemasan dan semua domain kelelahan. Uji statistik ini digunakan sebagai alternatif karena tidak berdistribusi normal setelah dilakukan uji normalitas menggunakan Kolmogorov-Smirnov. Tingkat signifikansi yang digunakan dalam penelitian ini yaitu 0,05 .

\section{HASIL}

\section{Deskripsi Data Demografi Partisipan}

Data demografi dari 70 partisipan digambarkan pada Tabel 1. Usia rata-rata partisipan adalah 53,91 tahun $(\mathrm{SD}=11,26)$, dengan interval 20-76 tahun. Lamanya mengidap TB rata-rata 5,60 bulan $(\mathrm{SD}=4,01)$, dengan rentang 1-13 bulan. Mayoritas partisipan adalah perempuan $45(64,3 \%)$ dan memiliki tingkat pendidikan tertinggi SMA sebanyak 35 (50,0\%). Partisipan yang menikah sebanyak 55 orang $(78,6 \%)$. Petani adalah pekerjaan dengan presentasi terbanyak dengan 30 partisipan $(42,9 \%)$. Terkait rokok, partisipan perokok yang sudah berhenti cukup dominan dengan jumlah 32 orang $(45,7 \%)$.

Tabel 1. Data demografi partisipan $(n=70)$

\begin{tabular}{lc}
\multicolumn{1}{c}{ Variabel } & Rata-rata \pm SD / n $(\%)$ \\
\hline Umur & $53,91 \pm 11,26$ \\
Jenis Kelamin & $25(35,7)$ \\
Laki-laki & $45(64,3)$ \\
Perempuan & \\
Pendidikan & $3(4,3)$ \\
Tidak sekolah & $10(14,3)$ \\
SD & $16(24,8)$ \\
SMP & $35(50,0)$ \\
SMA & $6(8,6)$ \\
Sarjana & \\
Pernikahan & $55(78,6)$ \\
Menikah & $15(21,4)$ \\
Tidak menikah & \\
Pekerjaan & $30(42,9)$ \\
Petani & $6(8,6)$ \\
PNS & $13(18,6)$ \\
IRT & $13(18,6)$ \\
Wirawasta & $5(7,1)$ \\
Tidak bekerja & $3(4,3)$ \\
Lainnya & \\
Merokok & $10(14,3)$ \\
Ya, masih aktif & $32(45,7)$ \\
Ya, sudah berhenti & $28(40,0)$ \\
Tidak pernah & $5,60 \pm 4,01$ \\
Durasi TB & $S D(a h$
\end{tabular}

Catatan: TB=Tuberkulosis; $S D=$ Sekolah Dasar; $S M P=$ Sekolah Menengah Pertama; SMA=Sekolah Menengah Atas; PNS=Pegawai Negeri Sipil; IRT=Ibu Rumah Tangga.

\section{Deskripsi Kecemasan Partisipan}

Tabel 2 mendeskripsikan skor setiap pernyataan dan dan kategori kecemasan partisipan. Terdapat nilai tertinggi pada pernyataan 10, yaitu gejala pada bagian pernapasan dengan skor 2,56 (SD =0,92). Sedangkan nilai terendah pada pernyataan 7 , tentang gejala somatik (otot) dengan skor ratarata 1,50 $(\mathrm{SD}=0,63)$. Skor rata-rata kecemasan (HAM-A) keseluruhan dari 70 partisipan yaitu $38,33$ ( $\mathrm{SD}=7,86)$. Tidak ada partisipan yang tergolong dalam kategori 1 (tidak ada kecemasan). Sebaliknya, mayoritas partisipan masuk dalam kategori 4 (kecemasan berat) sebanyak 31 orang $(44,3 \%)$.

Tabel 2. Skor setiap pernyataan kecemasan dan kategorinya $(n=70)$

\begin{tabular}{clc}
\hline No. & \multicolumn{1}{c}{ Pernyataan } & Rata-rata \pm SD \\
\hline 1 & Perasaan kecemasan & $2,03 \pm 1,10$ \\
2 & Ketegangan & $1,97 \pm 0,72$ \\
\hline
\end{tabular}




\begin{tabular}{|c|c|c|}
\hline No. & Pernyataan & Rata-rata \pm SD \\
\hline 3 & Ketakutan & $1,54 \pm 0,73$ \\
\hline 4 & Gangguan tidur & $2,16 \pm 0,88$ \\
\hline 5 & Gangguan kecerdasan & $2,50 \pm 1,00$ \\
\hline 6 & Perasaan depresi & $2,19 \pm 0,87$ \\
\hline 7 & Gejala somatik (otot) & $1,50 \pm 0,63$ \\
\hline 8 & $\begin{array}{l}\text { Gejala somatik } \\
\text { (penglihatan) }\end{array}$ & $1,76 \pm 0,87$ \\
\hline 9 & $\begin{array}{l}\text { Gejala pada bagian } \\
\text { jantung }\end{array}$ & $1,90 \pm 0,74$ \\
\hline 10 & $\begin{array}{l}\text { Gejala pada bagian } \\
\text { pernapasan }\end{array}$ & $2,56 \pm 0,92$ \\
\hline 11 & Gejala gastrointestinal & $1,77 \pm 0,61$ \\
\hline 12 & $\begin{array}{l}\text { Gejala pada bagian } \\
\text { sistem perkemihan }\end{array}$ & $1,81 \pm 0,79$ \\
\hline 13 & Gejala otonom & $2,41 \pm 0,71$ \\
\hline 14 & $\begin{array}{l}\text { Tingkah laku saat } \\
\text { wawancara }\end{array}$ & $2,26 \pm 1,07$ \\
\hline & HAM-A & $38,33 \pm 7,86$ \\
\hline No. & Kategori Kecemasan & n $(\%)$ \\
\hline 1 & Tidak ada kecemasan & $0(0)$ \\
\hline 2 & Kecemasan ringan & $13(18,6)$ \\
\hline 3 & Kecemasan sedang & $23(32,9)$ \\
\hline 4 & Kecemasan berat & $31(44,3)$ \\
\hline 5 & Kecemasan berat sekali & $3(4,3)$ \\
\hline
\end{tabular}

Catatan: HAM-A=Hamilton Anxiety Rating Scale.

\section{Deskripsi Kelelahan Partisipan}

Skor rata-rata setiap pertanyaan, domain, dan nilai global kelelahan atau GFI terdapat pada Tabel 3. Skor GFI berkisar antara 6-14 dengan rata-rata 24,60 $(\mathrm{SD}=7,83)$. Domain keparahan memiliki rata-rata $5,19(\mathrm{SD}=1,91)$, sedangkan tekanan 4,40 $(\mathrm{SD}=2,11)$. Skor rata-rata domain derajat terganggunya aktivitas memiliki rerata 4,14 $(\mathrm{SD}=1,46)$, sedangkan waktu yaitu 2,14 $(\mathrm{SD}=0,68)$.

Domain keparahan kelelahan terdiri atas 2 pertanyaan. Pertanyaan dengan nilai tertinggi yaitu pertanyaan no. 1 "pada tingkatan manakah anda merasa kelelahan?" dengan nilai rata-rata $5,70(\mathrm{SD}=1,76)$, di mana frekuensi tertinggi terdapat pada skor 5 dengan jumah $19(27,1 \%)$, Nilai terendah untuk domain keparahan yaitu pertanyaan no 2. "seberapa beratkah kelelahan yang anda telah rasakan?" dengan nilai rata-rata $5,30$ ( $\mathrm{SD}=2,08)$ dengan pilihan jawaban terbanyak pada skor 5 dengan jumlah 22 partisipan $(31,4 \%)$.

Domain tekanan hanya memiliki satu pertanyaan, "seberapa jauh kelelahan menyebabkan anda merasa tertekan?" bernilai rata-rata 4,39 $(\mathrm{SD}=2,14)$, dengan nilai frekuensi terbanyak terdapat pada skor 5 , dipilih oleh 20 partisipan $(28,6 \%)$.
Domain derajat terganggunya aktivitas mempunyai 11 pertanyaan. Nilai rata-rata tertinggi pada pertanyaan tentag "bekerja" yaitu $6,04(\mathrm{SD}=2,18)$, nilai frekuensi tertingginya pada skor 7 dengan 16 partisipan (22,9\%). Sementara itu, nilai terendah pada domain ini terdapat pada pertanyaan "melakukan hubungan seksual" dengan rata-rata 2,93 $(\mathrm{SD}=2,70)$ dan frekuensi tertinggi terdapat pada skor 0 dengan nilai $25(35,7 \%)$.

Domain waktu memiliki 2 pertanyaan. Skor tertinggi terdapat pada pertanyaan no. 15 yaitu "selama seminggu terakhir, seberapa sering anda merasa kelelahan?" yaitu 2,06 (SD = $0,76)$, skor 2 adalah pilihan jawaban yang paling sering dipilih dengan nilai 45 partisipan $(64,3 \%)$. Nilai terendah domain waktu berada pada pertanyaan "bagaimana perubahan tingkat kelelahan anda selama seminggu terakhir?" dengan rata-rata 2,21 $(\mathrm{SD}=0,81)$. Skor 2 dan 3 berbagi nilai terbanyak yang sama dengan jumlah 28 partisipan $(40,0 \%)$.

Tabel 3. Skor pertanyaan kelelahan, domain, dan GFI $(\mathrm{n}=70)$

\begin{tabular}{|c|c|c|}
\hline No. & Domain/Pertanyaan & Rata-rata \pm SD \\
\hline \multicolumn{2}{|c|}{ Domain keparahan } & $5,19 \pm 1,91$ \\
\hline \multirow[t]{3}{*}{1} & Pada tingkatan & \\
\hline & manakah Anda merasa & \\
\hline & kelelahan? & $5,70 \pm 1,76$ \\
\hline \multirow[t]{2}{*}{2} & Seberapa beratkah & \\
\hline & $\begin{array}{l}\text { kelelahan yang Anda } \\
\text { telah rasakan? }\end{array}$ & $5,30 \pm 2,08$ \\
\hline \multicolumn{2}{|c|}{ Domain Tekanan } & $4,40 \pm 2,11$ \\
\hline \multirow[t]{4}{*}{3} & Seberapa jauh & \\
\hline & kelelahan & \\
\hline & menyebabkan Anda & \\
\hline & merasa tertekan? & $4,39 \pm 2,14$ \\
\hline \multicolumn{3}{|c|}{ Domain derajat } \\
\hline \multicolumn{2}{|c|}{ terganggunya aktivitas } & $4,14 \pm 1,46$ \\
\hline \multirow[t]{2}{*}{4} & Melakukan pekerjaan & \\
\hline & rumah tangga & $4,16 \pm 2,88$ \\
\hline 5 & Memasak & $3,13 \pm 2,58$ \\
\hline 6 & Mandi atau mencuci & $4,61 \pm 2,20$ \\
\hline 7 & Berpakaian & $3,87 \pm 2,59$ \\
\hline 8 & Bekerja & $6,04 \pm 2,18$ \\
\hline \multirow[t]{2}{*}{9} & $\begin{array}{l}\text { Berkunjung atau } \\
\text { bersosialisasi dengan } \\
\text { teman-teman atau }\end{array}$ & \\
\hline & keluarga & $3,84 \pm 2,26$ \\
\hline \multirow[t]{2}{*}{10} & Melakukan hubungan & \\
\hline & seksual & $2,93 \pm 2,70$ \\
\hline 11 & $\begin{array}{l}\text { Melakukan kegiatan } \\
\text { santai dan rekreasi }\end{array}$ & $5,78 \pm 1,30$ \\
\hline
\end{tabular}




\begin{tabular}{clc}
\hline No. & Domain/Pertanyaan & Rata-rata \pm SD \\
\hline 12 & Berbelanja dan & \\
& melakukan suatu & $5,63 \pm 1,30$ \\
& urusan & $4,85 \pm 1,58$ \\
13 & Jalan kaki & \\
14 & Berolahraga, selain & $5,99 \pm 1,79$ \\
& jalan kaki & $2,14 \pm 0,68$ \\
Domain waktu & \\
15 & Selama seminggu & \\
& terakhir, seberapa & \\
& sering Anda merasa & \\
& kelelahan? & \\
16 & Bagaimana perubahan & \\
& tingkat kelelahan anda & \\
& selama seminggu & \\
& terakhir? & $2,06 \pm 0,76$ \\
& GFI
\end{tabular}

Catatan: GFI=Global Fatigue Index.

\section{Korelasi Kecemasan dan Domain Kelelahan}

Tabel 4 menyajikan hubungan antara kecemasan dan kelelahan (terbagi dalam 4 domain dan GFI). Kecemasan yang diwakili oleh skor HAM-A tidak memiliki hubungan yang signifikan dengan GFI sebagai skor kelelahan secara keseluruhan $(r=0,15, p>0,05)$. Kecemasan didapati tidak memiliki hubungan yang signifikan dengan domain keparahan $(r=$ $0,01, p>0,05)$. Kecemasan dan derajat terganggunya aktivitas juga tidak memiliki hubungan yang signifikan $(r=0,23, p>0,05)$. Hal yang sama juga ditemukan antara kecemasan dan domain waktu $(r=0,13, p>$ $0,05)$. Kecemasan hanya ditemukan memiliki korelasi positif yang signifikan dengan domain tekanan dengan level keeratan yang sangat lemah $(r=0,24, p<0,05)$.

Tabel 4. Matriks koefisien korelasi kecemasan dan domain kelelahan $(\mathrm{n}=70)$

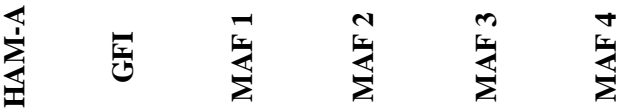

HAM-A 1

GFI $\quad 0,15 \quad 1$

MAF $1 \quad 0,01 \quad 0,85^{* *} \quad 1$

$\begin{array}{lllll}\text { MAF } 2 & \mathbf{0 , 2 4} * & 0,84 * * & 0,68 * * & 1\end{array}$

$\begin{array}{llllll}\text { MAF } 3 & 0,23 & 0,76 * * & 0,65 * * & 0,58 * * & 1\end{array}$

$\begin{array}{lllllll}\text { MAF } 4 & 0,13 & 0,50 * * & 0,27 * & 0,31 * * & 0,36 * * & 1\end{array}$

Catatan: $* p<0,05, * * p<0,01$, HAM-A=Hamilton Anxiety

Rating Scale; GFI=Global Fatigue Index;

$M A F=$ Multidimensional Assesment of Fatigue, MAF

1=Keparahan; MAF 2=Tekanan; MAF 3=Derajat

Terganggunya Aktivitas; $M A F 4=$ Waktu.

\section{PEMBAHASAN}

Pada penelitian ini, pasien TB berumur rata-rata 53,91 dengan rentang 20-76 tahun. Penelitian Dotulong, Sapulete, dan Kandou (2015) menyebutkan bahwa kelompok umur di atas 55 tahun adalah kelompok umur yang kemungkinan terpapar dengan kuman Mikobakterium Tuberkulosis paru lebih besar, sehubungan dengan mobilitas yang tinggi. Selain itu reaktifan endogen (kembali aktifnya dalam tubuh) dapat terjadi pada usia yang sudah tua.

Kelompok jenis kelamin yang terdominan dalam penelitian ini adalah perempuan. Hasil ini sedikit berbeda dengan penelitian Kibrisli et al. (2015) yang mendapati dari 94 pasien yang terdiagnosa TB paru, idominasi oleh pria. Frekuensi kebiasaan merokok dan rendahnya kepatuhan pengobatan pada pria seringkali menjadi alasan utama terkait hal ini (Kementerian Kesehatan Republik Indonesia, 2018). Lebih dari 500 ribu pasien TB perempuan meninggal setiap tahun, yang mayoritas disebabkan oleh masalah sosial, psikologis, dan diskrimiinasi (Srivastava, Kant, Narain, \& Bajpai, 2018).

Secara global, laki-laki lebih banyak menderita TB dibanding perempuan, namun di beberapa lokasi seperti Afghanistan dan Pakistan yang berdekatan dengan Afghanistan dan Iran, ditemukan sebaliknya. Di Afrika, TB meningkat 10 kali lebih tinggi pada perempuan hamil yang menderita HIV dibandingkan yang tidak. Meningkatnya penggunaan rokok dan diabetes pada perempuan, menambah beban penderitaan karena TB. Masalah budaya dan finansial juga menjadi penghambat bagi perempuan sehingga memperlambat diagnosis dan memperparah penyakit. TB terutama menyerang perempuan pada saat mereka aktif secara ekonomi dan reproduksi. Ketakutan dan stigma terkait TB mempunyai dampak yang lebih besar pada perempuan dan sering menyebabkan situasi sosial dan ekonomi, di mana dampaknya juga sangat dirasakan oleh anak dan keluarganya (World Health Organization, 2019).

Penelitian ini menemukan bahwa pekerjaan terbanyak partisipan adalah petani. Lokasi kerja petani yang sering berada di luar ruangan dengan kondisi lingkungan yang terbuka dan tanpa menggunakan alat pelindung diri beresiko terhadap terpaparnya kuman TB. Diperparah lagi dengan tidak begitu 
mementingkan pola hidup. Hasil penelitian ini cukup kontras dengan temuan Duko et al. (2015) yang menyatakan bahwa partisipan yang paling terbanyak terpapar bekerja sebagai karyawan pemerintah dan swasta, sedangkan petani adalah kelompok paling minoritas. Hal ini juga terlihat sejalan dengan tingkat pendidikan partisipan, yang menunjukkan bahwa mereka yang berpendidikan lebih rendah, mempunyai frekuensi yang lebih tinggi dalam hal penyakit TB.

Partisipan dalam penelitian mayoritas mengalami kecemasan berat. Penelitian ini cukup mirip dengan temuan penelitian Sumartini (2013) yang menemukan kecemasan berat dan sedang adalah yang tertinggi di antara penderita TB paru. Timbulnya kecemasan pada penyakit TB dapat menyebabkan penurunan fungsi pada hipotalamus, di mana salah satu gejalanya yaitu kelelahan (Shaikh, 2020). Gejala yang sama juga dapat muncul jika terjadi infeksi TB langsung pada kelenjar adrenal (Huang et al., 2015). Ketika pasien didiagnosa menderita penyakit $\mathrm{TB}$, pasien wajib menghabiskan obat anti $\mathrm{TB}$ dalam waktu yang relatif cukup lama dengan jumlah obat yang banyak, sehingga dapat menimbulkan suatu perasaan khawatir tentang kemampuan menjalankan program pengobatan tersebut. Konsekuensi program tersebut juga menimbulkan kecemasan (Berman et al., 2018).

Hampir keseluruhan pasien TB didapatkan menderita kelelahan dengan rata-rata skor pada derajat sedang. Hasil ini identik dengan studi di Thailand yang menemukan bahwa lebih dari tiga perempat partisipan menderita kelelahan dan mayoritas tergolong pada tingkat moderat (Thedthong et al., 2021). Dalam penelitian ini didapati bahwa semakin penderita TB merasa cemas, maka kelelahan secara mental makin memburuk. Adanya peningkatan mediator sitokin dalam waktu yang lama pada penyakit kronis seperti TB akan menimbulkan gangguan metabolisme sel sebagai reaksi tubuh saat radang. Tekanan pada saraf simpatis berpotensi terjadi, sehingga dapat berakibat pada menurunnya curah jantung dan tekanan darah sehingga sirkulasi terganggu. Hal inilah yang menyebabkan secara berkesinambungan kelelahan terjadi pada pasien. Khusus pada pasien TB, proses peradangan dan infeksilah yang sering menyebabkan kelelahan. Gangguan psikologis berupa perasaan tidak berdaya, cemas, depresi, dan stres juga merupakan penyebab kelelahan pada penyakit infeksi kronis (Nugraha \& Ramdhanie, 2018).

Kecemasan merupakan hasil dari pasien mengolah informasi pada situasi yang dianggap sebagai suatu ancaman respon psikologik dalam keadaan tertekan di mana terdapat perasaan takut yang menciptakan suasana hati tidak kondusif sehingga ketenangan seseorang berkurang dan muncul rasa keragu-raguan (Ibrahim, 2014). Hal ini juga didukung oleh Yasmin (2017) yang menyatakan bahwa gejala dari kecemasan yang meningkat termasuk salah satunya dibarengi peningkatan kelelahan selain ganguuan fisik dan psikis lainnya seperti otot yang menegang, bicara lebih cepat, sulit berkonsentrasi, iritasi perasaan, dan gangguan emosional lainnya.

Terdapat beberapa keterbatasan yang diamati dalam penelitian ini. Sampel dalam penelitian ini relatif cukup kecil dan sulit untuk dilakukannya generalisir pada populasi TB secara keseluruhan. Pendekatan potong lintang yang diterapkan dalam penelitian ini juga, terasa kurang untuk merepresentasi keadaan kecemasan dan kelelahan pada penderita TB, karena hanya dilakukan pengambilan data pada suatu periode tertentu, tanpa adanya pengulangan, guna mengetahui kondisi yang sesungguhnya secara berkesinambungan.

\section{KESIMPULAN DAN SARAN}

Kecemasan dan kelelahan lazim ditemukan pada pasien TB. Penelitian ini menunjukkan seluruh partisipan mengalami kecemasan dengan skor rata-rata berada di level sedang-tinggi, di mana kategori kecemasan berat adalah yang terdominan. Hampir semua partisipan mengalami kelelahan, dengan skor rata-rata berskala sedang pada setiap domain dan kelelahan secara umum. Pasien TB yang mengalami kecemasan berat, menderita kelelahan mental yang lebih parah. Skrining kecemasan dapat membantu identifikasi pasien yang memerlukan penilaian psikososial tahap lanjut. Kelelahan adalah faktor yang dapat dikelola, oleh karena itu perawat harus menyadari pentingnya pengkajian kecemasan yang konsisten untuk mencegah dan mengurangi faktor yang berhubungan dengannya, yang diharapkan dapat membantu pemulihan TB paru dan berpotensi meningkatkan kualitas hidup. Penelitian serupa selanjutnya disarankan mempertimbangkan beberapa faktor spesifik lainnya seperti kepatuhan mengonsumsi obat, 
keterlibatan penyakit penyerta yang penting seperti HIV, maupun pengukuran secara objektif dengan jumlah sampel yang lebih besar. Temuan dalam penelitian ini diharapkan juga dapat menstimulasi adanya penelitian-penelitian eksperimental untuk memperbaiki status psikologis seperti kecemasan dan kelelahan, baik fisik maupun mental yang berfokus pada pasien TB.

\section{DAFTAR PUSTAKA}

Amreen, \& Rizvi, N. (2016). Frequency of depression and anxiety among tuberculosis patients. Journal of Tuberculosis Research, 4, 183-190. https://doi.org/10.4236/jtr.2016.44021

Belza, B. L., Henke, C. J., Yeun, E., Epstein, W. V., \& Gauss, C. I. (1993). Correlates of fatigue in older adults with rheumatoid arthritis. Nursing Research, 42(2), 93-99. https://doi.org/10.1097/00006199199303000-00006

Berman, A., Snyder, S. J., Levett-Jones, T., Dwyer, T., Hales, M., Harvey, N., ... Stanley, D. (2018). Kozier and Erb's fundamentals of nursing: Concepts, process, and practice (4th ed.). Melbourne: Pearson Australia. Retrieved from

https://researchonline.jcu.edu.au/51992/

Dias, A. A. L., de Oliveira, D. M. F., Turato, E. R., \& de Figueiredo, R. M. (2013). Life experiences of patients who have completed tuberculosis treatment: A qualitative investigation in southeast Brazil. BMC Public Health, 13(1), 595. https://doi.org/10.1186/1471-2458-13595

Dotulong, J., Sapulete, M. R., \& Kandou, G. D. (2015). Hubungan faktor risiko umur, jenis kelamin dan kepadatan hunian dengan kejadian penyakit TB paru di desa Wori kecamatan Wori. Jurnal Kedokteran Komunitas Dan Tropik, 3(2), 57-65. Retrieved from https://ejournal.unsrat.ac.id/index.php/JK KT/article/view/7773/7336

Duko, B., Gebeyehu, A., \& Ayano, G. (2015). Prevalence and correlates of depression and anxiety among patients with tuberculosis at WolaitaSodo University Hospital and Sodo Health Center, WolaitaSodo, South Ethiopia, Cross sectional study. BMC Psychiatry, 15, 214. https://doi.org/10.1186/s12888-0150598-3

Hamilton, M. (1959). The assessment of anxiety states by rating. British Journal of Medical Psychology, 32(1), 50-55. https://doi.org/10.1111/j.20448341.1959.tb00467.x

Huang, Y.-C., Tang, Y.-L., Zhang, X.-M., Zeng, N.-L., Li, R., \& Chen, T.-W. (2015). Evaluation of primary adrenal insufficiency secondary to tuberculous adrenalitis with computed tomography and magnetic resonance imaging: Current status. World Journal of Radiology, 7(10), 336-342.

https://doi.org/10.4329/wjr.v7.i10.336

Ibrahim, A. S. (2014). Panik neurosis dan gangguan cemas. Tangerang: Jelajah Nusa.

Kementerian Kesehatan Republik Indonesia. (2018). Tuberkulosis (TB). Jakarta. Retrieved from https://pusdatin.kemkes.go.id/resources/d ownload/pusdatin/infodatin/infodatintuberkulosis-2018.pdf

Khusniyati, N., Yona, S., \& Kariasa, I. M. (2019). Fatigue, Depresi, Terhadap Kualitas Hidup Pada Pasien Hemodialisa. Jurnal Keperawatan Terpadu (Integrated Nursing Journal), $1(2), \quad 1$. https://doi.org/10.32807/jkt.v1i2.30

Kibrisli, E., Bez, Y., Yilmaz, A., Aslanhan, H., Taylan, M., Kaya, H., ... Abakay, O. (2015). High social anxiety and poor quality of life in patients with pulmonary tuberculosis. Medicine, 94(3), 1-6. https://doi.org/10.1097/MD.0000000000 000413

Kumar, K., Kumar, A., Chandra, P., \& Kansal, H. M. (2016). A study of prevalence of depression and anxiety in patients suffering from tuberculosis. Journal of Family Medicine and Primary Care, 5(1), 
150-153. https://doi.org/10.4103/22494863.184641

Lainsamputty, F., \& Chen, H.-M. (2018). The correlation between fatigue and sleep quality among patients with heart failure. NurseLine Journal, 3(2), 100-114. https://doi.org/10.19184/nlj.v3i2.8580

Liao, J., Zhang, D., \& Wu, X. (2015). Pulmonary tuberculosis combined with hepatic tuberculosis: A case report and literature review. The Clinical Respiratory Journal, 9(4), 501-505. https://doi.org/10.1111/crj.12167

Nugraha, B. A., \& Ramdhanie, G. G. (2018). Kelelahan pada pasien dengan penyakit kronis. Prosiding Seminar Nasional Dan Penelitian Kesehatan 2018. Tasikmalaya.

Santos, A. P. C. dos, Lazzari, T. K., \& Silva, D. R. (2017). Health-related quality of life, depression and anxiety in hospitalized patients with tuberculosis. Tuberculosis and Respiratory Diseases, 80(1), 69-76. https://doi.org/10.4046/trd.2017.80.1.69

Shaikh, J. (2020). What are the symptoms of a malfunctioning hypothalamus? Retrieved August 30, 2020, from https://www.medicinenet.com/symptoms _of_a_malfunctioning_hypothalamus/arti cle.htm

Srivastava, K., Kant, S., Narain, A., \& Bajpai, J. (2018). Tuberculosis in women: A reflection of gender inequity. European Respiratory Journal, 52(suppl 62), PA531.

https://doi.org/10.1183/13993003.congre ss-2018.PA531

Sumartini, N. P. (2013). Hubungan tingkat pengetahuan tentang $\mathrm{TB}$ paru dengan kecemasan pada penderita TB Paru di Instalasi Rawat Inap RSUP NTB. Jurnal Publikasi Ilmiah, 105-117.

Thedthong, W., Puwarawuttipanich, W., Saneha, C., \& Rongrunguang, Y. (2021). Factors predicting fatigue in pulmonary tuberculosis patients receiving antituberculosis drugs. Siriraj Medical Journal, $\quad$ 73(3), $\quad 167-173$.
https://doi.org/10.33192/Smj.2021.22

Wang, X., Li, X., Zhang, Q., Zhang, J., Chen, H., \& Zhang, J. (2018). A survey of anxiety and depressive symptoms in pulmonary tuberculosis patients with and without tracheobronchial tuberculosis. Frontiers in Psychiatry, 9(July), 1-10. https://doi.org/10.3389/fpsyt.2018.00308

World Health Organization. (2016). Global tuberculosis report 2016. Geneva. Retrieved from https://apps.who.int/iris/handle/10665/25 0441

World Health Organization. (2019). Tuberculosis in women. Retrieved from https://www.who.int/tb/publications/tb_w omen_factsheet.pdf?ua=1

Yasmin, A. M. (2017). Hubungan antara dukungan keluarga dengan kecemasan pada remaja pengidap HIV/AIDS. 5(3), 382-387. Retrieved from http://ejournals.unmul.ac.id/index.php/psikoneo/ article/view/4424/pdf

Yilmaz, A., \& Dedeli, O. (2016). Assessment of anxiety, depression, loneliness and stigmatization in patients with tuberculosis. Acta Paulista de Enfermagem, 29(5), 549-557. https://doi.org/10.1590/19820194201600076 